\title{
PART 4. \\ CONFESSIONAL-ETHNIC AND POLITICAL TRANSFORMATIONS DURING THE SECOND WORLD WAR (1939-1945)
}

The middle, as well as the beginning of the twentieth century, had brought great ethno-religious transformations to Ukraine. Ukrainians were challenged by a new world war, mass repression of the Stalinist and Hitler's regimes. Ukrainians have suffered the greatest demographic losses among all the nations of Europe: scientists estimate that today the population of Ukraine could have reached approximately 100 million $^{312}$. Western Ukrainian areas were constantly in the center of military and political confrontation and armed struggle of foreign states. The church-religious complex of the region, that was annexed to the USSR as a result of World War II, has been damaged ${ }^{313}$. The confrontation of the church to the new communist government ended in disaster.

Under the totalitarian regime in the USSR, the priority of the ruling Communist Party was the struggle for influencing people's consciousness, its denationalization. The concepts of Christian morality were not within the ideological framework of the system. Consequently, the relations of the militant-atheist government with the church in Ukraine, whose people have always been deeply religious, often took radical confronting forms. After the affiliation of Western Ukraine to the USSR in the fall of 1939 and the defeat of the Ukrainian Orthodox Church in the Soviet Ukraine and the elimination of denominations that were supporting independence of the state and clergy, Moscow faced an organizationally strong and dangerous opponent - the UGCC.

312 Кульчицький С. Нi, то не був подарунок долі. Високий Замок. 1999. 18 серпня.

313 Литвин М., Луцький О., Науменко К. 1939. Західні землі України. Львів, 1999. $152 \mathrm{c}$ 
Before World War II, the Greek Catholic Church was one of the most respected in the Second Polish Republic and played a prominent role in the socio-political and national-cultural life of Western Ukraine. Its majestic structure consisted of 3040 parishes uniting 4.3 million believers, 4440 temples and chapels, the Theological Academy in Lviv, five theological seminaries, two theological schools, 127 monasteries and monastic houses ${ }^{314}$. The UGCC was the generator of the historical memory and national consciousness of Galician Ukrainians and resisted to the assimilatory policy of Warsaw. The guarantor of the ethnocentric course of the church in the XX century was its Metropolitan Andrey Sheptytsky - a man with the extraordinary human and civil qualities, an experienced parliamentarian, a consistent supporter of national and cultural rights of the people. The church under his authority in 1939 had 10 bishops, 2,950 priests, 520 hieromonks, 1,090 nuns and 540 theology students $^{315}$. The UGCC facilitated the development of Ukrainian business life, the formation of national economic, production, banking and museum structures, it was engaged in charity and philanthropy. Besides the Greek Catholics there were numerous and organized denominations of Roman Catholics ( 2 million), Orthodox (1.5 million, mainly in Volyn and Chelm) and Jews (0.8 million) ${ }^{316}$.

After the Western Ukraine's annexation in the fall of 1939, the Bolshevik authorities, providing the so-called "sovietization" of these lands, launched a widespread attack on religion and in particular on the Greek Catholic Church, as an important factor in the spiritual and political life of the region. First of all, its educational institutions were closed: The Theological Academy, theological seminaries, scientific

${ }^{314}$ Реєнт О.П., Лисенко О.С. Українська національна ідея і християнство. Київ: Богдана. 1997. С. 94.

315 Гордієнко В. Сталінізм і Українська греко-католицька церква. Матеріали міжнародної конферениї присвяченої життю $i$ діяльності митрополита Андрея Шептицького. Львів, 1990. С. 43.

316 ЦДІАУЛ. Ф. 358. Оп. 1. Спр. 112, 114, 118, 119, 124, 126, 128, 129, 132; Макарчук С. Этносоциальное развитие и национальные отношения на западноукраинских землях в период империализма. Львов, 1983. С. 146-148; Ковалюк В. Культурологічні та духовні аспекти «радянізації» Західної України (вересень 1939 - червень 1941). Украӥнський історичний журнал. 1993. № 2. C. 10 . 
institutions (Theological Scientific Society, etc.), publishing houses, religious publications were suspended and teaching of religion in schools and universities was cancelled. In other words, the first stage of the "sovietization" of the spiritual life of society was provided by eliminating the influence of the church on the believers.

The new authorities also made a huge damage to the Roman Catholic Church. "Priests and rabbis, those faithful slaves of the enemies, are actively manifesting their anti-people's activities", the Moscow magazine "Communist Education" noted on that days ${ }^{317}$. The NKVD structures, as well as the party and state authorities, followed the directive of the People's Commissar for Internal Affairs of the USSR L. Beria from September 15, 1939: "to clear the annexed territories from "hostile elements". They used well-known methods of struggle for the power - the mass repressions. Therefore, the priests were in the first wave of arrests and deportations in February 1940, when hundreds of thousands of Westerners were deported to the North and to Siberia ${ }^{318}$.

The repressive measures of the Soviet authorities did not bypass their serious opponent, the UGCC. On the first day of the war, on September 1, 1939, when the German bombardment of the Ukrainian cities of Lviv, Ternopil, Stanislaviv had started, the Metropolitan ordination addressed the clergy with a request to remain calm and warn the believers against the ideological invasion of provocateurs and communists ${ }^{319}$.

The new regime interpreted the historical mission of the Greek Catholic Church very carefully and step by step restricted its activities. Metropolitan A. Sheptytsky wrote in a letter to Rome on December 26, 1939: The Bolsheviks made great efforts "only to conquer, oppress, and destroy us". Summing up the consequences of the criminal acts of the authorities, he emphasized: "The number of victims who were deported, imprisoned or killed is very high. Only in

${ }^{317}$ Комуністична освіта. 1940. № 9. С. 18.

318 Депортації. Західні землі України кінця 30-х - поч. 50-х рр. Т. 1. Львів, 1996; Депортації українців та поляків: кінець 1939 - початок 50-х років. Львів, 1998. С. 74-76.

319 Сурмач О. Державно-церковні відносини на західноукраїнських землях (1939-1941). 1939 рік в історичній долі Украӥни і українців. Львів, 2001. С. 171. 
my eparchy, it is about 20,000 people. In my eparchy 12 priests were killed or died in prison, and about 20 in the Przemysl Eparchy. In addition, 33 priests were deported from my eparchy to Siberia" ${ }^{320}$. It should be emphasized that about one hundred priests moved across the San River to the German territory threatened by repressions.

Under such difficult conditions of the militant atheism system, the Greek Catholic Church had the smallest amount of loss among other denominations and was able to resist the Bolshevik anti-religious policies in an organized and effective manner. This merit belongs primarily to Metropolitan Andrey, who united the clergy and consistently followed the course he proclaimed concerning the new authorities, which was not favorable to $\mathrm{it}^{321}$. Lviv historian of the church Mykhaylo Haikovsky rightly points out that in one of the messages Andrey Sheptytsky clearly stated the approach of the Greek Catholic Church to the Bolshevik authorities. According to his words, "to obey the Laws, because they are not contrary to God's law", as well as to "not interfere with politics and secular affairs", there is a transparent position. He called not to support the new authorities, which from the first days tried to involve the masses in the political struggle of the poor against the rich, the bourgeoisie and other "enemies of the people"322.

Nevertheless, Moscow and Kyiv still abstained from radical measures to eliminate the UGCC, although its anti-Soviet orientation was well known. In our opinion, a radical course to eliminate the Greek Catholic Church - a recognized defender of the interests of the Ukrainian people in Poland - would contradict J. Stalin's main argument regarding the September 17, 1939 invasion: "to take under protection the Ukrainian population". The important thing is that on September 27 of the same year, after the start of the war actions by the Red Army, the Kyiv radio expressed gratitude to the Galician clergy for having "supported so faithfully the Ukrainian spirit of the

\footnotetext{
${ }^{320}$ Реєнт О.П., Лисенко О.С. Українська національна ідея і християнство. Київ: Богдана. 1997. С. 95.

321 Шептицький Андрей, митрополит. До духовенства. Львівські єпархіальні відомості. 1939. № 9-10. С. 205.

322 Гайковський М. Велике протистояння: опір греко-католицької церкви більшовицькому окупаційному режимові (вересень 1939 - червень 1941). Київська цеерква. 1999. № 5. С. 26.
} 
enslaved people",323. As V. Lentsyk rightly emphasized, two more important circumstances contributed to this: the uncertain situation in the region after the beginning of World War II, as well as the indisputable authority of Metropolitan Andrey Sheptytsky ${ }^{324}$.

Not daring liquidate the UGCC, the Soviet authorities used great economic oppression: they nationalized all church lands, confiscated a big amount of buildings, imposed excessive taxes. The monasteries had particularly significant losses. In the fall of 1939, the red "liberators" carried out a search in the Monastery in Hoshiv - they confiscated watches, razors and other things from the monks. All the buildings except the church were occupied by the army until 1941 and left furniture, pierced with bayonets, broken walls and doors ${ }^{325}$.

Church-religious magazines and publishing houses were liquidated. The activities of the Theological Scientific Society were prohibited. Its book collection was destroyed - 12,000 volumes, including 500 old books and manuscripts, 150 sets of journals in Ukrainian, Polish, Russian, German, English and other languages, as well as the scientific papers of theologians of the 1930's ${ }^{326}$.

Metropolitan sent an appeal letter directly to M. Khrushchev. In a letter, he informed the Secretary of the Central Committee of the CPSU about excessive taxes on clergy, the failure of which would lead to the prosecution of the priests. There is an impression, Metropolitan emphasized, that it was not so much about religious taxes ("cultural tax"), but "about the destruction of the Ukrainian clergy". At the same time, he drew M. Khrushchev's attention to extensive taxes on the peasants ${ }^{327}$.

When the People's Assembly of Western Ukraine in October 1939 adopted Declarations and decrees prepared in Moscow, including the confiscation of church lands and the liquidation of monasteries, Metropolitan Andrey Sheptytsky declared them illegal and openly protested. In a letter to the priesthood and monastic congregations,

\footnotetext{
${ }^{323}$ ЦДІАУЛ. Ф. 684. Оп. 2. Спр. 92. Арк. 95.

324 Західна Україна під большевиками. IX. 1939 - VI. 1941 / Збірник під редакцією М. Рудницької. Нью-Йорк, 1958. С. 143.

325 Яновський М. Правда про Гошівський монастир. Нова зоря. 1994. Січень. Ч. 2 .

326 Антонюк Н. В. Українське культурне життя в «Генеральній губернії» (19391944 рр.). Львів, 1997. С. 158.

${ }^{327}$ ЦДІАУЛ. Ф. 201. Оп. 4. Спр. 2632. Арк. 18.
} 
Metropolitan wrote indignantly: "The military circumstances have forced us to remain silent until now and not to be able to stand resolutely in your defense against violence. That is the most painful, because it had been covered by the lie expressed by the will of the people. This silence is contrary to our will. Let no one interpret that we agree with the spirit of violence. We do not agree, but we are also strongly protesting against the wrongdoing towards you" ${ }^{\text {"328. In }}$ particular, Metropolitan protested that part of the Declaration of the Peoples' Assembly, which proclaimed the confiscation of church lands and the liquidation of monasteries.

Metropolitan A. Sheptytsky did his best to maintain the church and its believers under new conditions. He prohibited the priests to leave the parishes, and continued to maintain relations with the Apostolic See. In October 1939, he secretly sent a trusted person to Pope Pius XII with a letter referring to the ordination of the rector of the Theological Academy Fr. Josyf Slipyj as the Bishop, the possible successor to the Metropolitan throne. Pope Pius XII, at the request of Metropolitan, approved the action of spreading the Uniate on the territory of the USSR, that was initiated by the secret Lviv Council of September 18-19, 1940. Metropolitan established four exarchates outside Galicia and appointed exarchs in the Soviet Ukraine (Bishop J. Slipyj), Russia (Student-monk K. Sheptytsky), Belarus (Bishop A. Nemantsevich), Volyn, Chelm region and Podlachia (Bishop M. Charnetsky). The main canonical, liturgical, and pastoral foundations of the new structure of the UGCC were established at the Council of the Exarchs. After some hesitations, Pope Pius XII approved the Exarchs as Apostolic at the end of 1941, and Metropolitan Andrey as the Apostolic Delegate for the Exarchs. So, under extremely difficult circumstances, the UGCC not only survived but also extended to a large territory of the East ${ }^{329}$. Metropolitan initiated the purification of the church from Latin rites, was preparing missionaries for apostolic work in the eastern regions, where many Ukrainian immigrants lived for a long time.

\footnotetext{
${ }^{328}$ ЦДІАУЛ. Ф. 358. Оп. 3. Спр. 12. Арк. 12-13.

329 Сапеляк А. Київська церква на слов'янському Сході. Буенос-Айрес; Львів: Інститут українознавства ім. І. Крип'якевича НАНУ, 1999. С. 168.
} 
According to the large number $(10 \%)$ of the deported population of the Western Ukraine ${ }^{330}$, Metropolitan tried to send Greek Catholic priests to their displacement areas (Siberia, Kazakhstan, the Far East). Moreover, he personally tried to go there ${ }^{331}$.

The annexation of the Western Ukrainian lands to the USSR was carried out with strong violation of the principles of international law. It was based on violence and ignoring of civilized norms of interstate relations and Christian morality. The policy of "sovietization" of 1939-1941 by totalitarian authorities in fact displaced the church from official social life and removed important social functions from it education, charity, financial and economic activities.

The beginning of the Soviet-German war on June 22, 1941 changed the religious situation in the Western Ukrainian lands, which were already occupied by the Wehrmacht troops in the first weeks of war. The OUN leadership, taking advantages of new geopolitical circumstances, proclaimed the Act of Restoration of the Ukrainian State on June 30, 1941 in Lviv. Very soon, on July 1, the Pastoral Letter of Metropolitan A. Sheptytsky stated: "With the will of the almighty and merciful God, united in the Trinity, a new era began in the life of the United State of Independent Ukraine. Military circumstances require many more victims, but this case, which was born in the name of God and with the grace of God will be brought to a successful end... The Ukrainian people must show in that historical wave that they have a sufficient sense of authority, solidarity and vitality to deserve a position among the peoples of Europe and develop it's own forces, that were given by God... We recognize Yaroslav Stetsko as the Head of the Regional Administration of the Western Regions of Ukraine. We expect from his government wise and fair governance, which will recognize and unite the needs and good of everyone living in our land despite the nationality or social strata ${ }^{332}$.

330 Депортації. Західні землі України кінця 30-х - початку 50-х рр. Документи, матеріали, спогади. Т. І. Львів, 1996. С. 8-12; Popiński K., Kokurin A. Drogi śmierci. Ewakuacja więzień sowieckieh z kresów Wschodnich II Rzeczy pospolitej w czerwcu i lipcu 1941. Warszawa, 1995. S. 7-74, 98-104.

${ }^{331}$ ЦДІАУЛ. Ф. 201. ОП. 1. Cnp. 4342. Арк. 25-40.

332 Українське державотворення. Акт 30 червня 1941. Збірник документів і матеріалів. Львів; Київ, 2001. С. 126. 
It is clear that the UGCC defended the independent aspirations of the Ukrainian people. On July 5, 1941, Metropolitan A. Sheptytsky addressed one more pastoral letter to the believers and called: "All those who feel themselves Ukrainians and want to work for the good of Ukraine, let them forget about any party division, let them work in unity and agreement over the restoration of our economic, intellectual and cultural life so much destroyed by the Bolsheviks"333. The Metropolitan was elected as a chairman of the National Council (members - J. Slipyj, G. Kostelnyk) ${ }^{334}$. The Council was soon destroyed by the German occupation authorities, and the members of the government led by Y. Stetsko were arrested and sent to Sachsenhausen concentration camp.

Despite the statements of the Soviet historiography and official propaganda of the communist regime, the UGCC has never been a collaborator, moreover an ally of the Nazis. The announced gratitude to the German army for the liberation from the Bolshevik regime was conditioned by the ending of the mass repressions, deportations and the bloody massacre of the NKVD before their escape. The residents of the region met the Act of June 30, 1941 with great enthusiasm and new hopes. These feelings are also present in Metropolitan A. Sheptytsky's message to the clergy and the believers on July 5, 1941. Metropolitan expressed the hope that "on the foundations of solidarity and hard work of all Ukrainians, United Ukraine will rise not only as a great word and idea, but as a living, healthy, powerful state organism, established on the sacrifice of the lives of certain people, and by the anthill work, the iron efforts and hard work of the others" ${ }^{335}$.

At first, the German authorities were loyal to the church, in particular to the Greek Catholic Church, and did not interfere into the manifestation of the religious feelings of the occupied population, the restoration of the activities of organizations, religious publishers, and educational institutions. Thanks to flexible diplomacy and tireless work of the St. George's throne, the UGCC gained more power and made its contributions to national and cultural life.

\footnotetext{
333 Церква і суспільне питання. Львів, 1999. Т. 2. Кн. 2. С. 924.

334 Пилипів I. Українська греко-католицька церква в період німецької окупації (1941-1944 рр.). Галичина. 2002. № 8. С. 108-115.

335 ЦДІАУЛ. Ф. 358. Оп. 1. Спр. 11. Арк. 25.
} 
The loyal relationship between the UGCC and the occupying authorities escalated into a confrontation in the fall of 1941, when Berlin openly expressed its invasive intentions on Ukraine and launched terror on its occupied lands against national movements, in particular the OUN. In the first pastoral letter to the believers in December 1941, Metropolitan A. Sheptytsky condemned the repressions, the arbitrariness of the Nazis, and called Ukrainians to maintain their national dignity, to defend their freedom, their families and communities ${ }^{336}$. Later, in August 1942, in a letter to Pope Pius XII, he openly emphasized: "The German authorities are evil, almost devilish, and much worse than the Bolshevik authorities" ${ }^{\prime 337}$.

In the pastoral letters, addresses of Metropolitan and other hierarchs of the church, the main calls were made toward national unity and harmony, which they considered to be a prerequisite for building an independent and powerful Ukrainian state. This thought is dominant in the already mentioned Metropolitan's message of July 5, 1941. Andrey Sheptytsky clearly affirms that United Ukraine will be built only under the conditions of solidarity and tireless work of all Ukrainians. At the same time, believers were called for religious unity, which should become the spiritual platform for the unification of all national forces during the war ${ }^{338}$.

In the same period, on July 20, 1941, the Galician press published "Metropolitan's letter to the clergy on the organization of the parish and the community". This pastoral letter outlined the urgent tasks of the priests during that difficult period: "In the first place it is necessary to take care of families and the property of the believers arrested and deported by the Bolsheviks. Their families need help, which the pastor should be glad to give by himself and organize so that widows, orphans, or women and children who were left without care of their father and husband for a long time, they have the right to

336 Шептицький Андрей, митрополит. Як будувати рідну хату? Митрополит Андрей Шептицький. Матеріали та документи (1865-1944). 2-ге видання / За редакцією Заборовського Я.Ю. Львів; Івано-Франківськ: Олір, 1995. С. 70-104.

337 Береславський М.3. 3 історії Української греко-католицької церкви. Львів, 1992. С. 30.

338 Шептицький Андрей, митрополит. Послання до духовенства i вірних Архієпархії. Львівські єпархіяльні відомості. 1942. Ч. 1. С. 9. 
seek that care from the church" 339 . Public attention was also drawn to the need to restore the national schools, as well as the activities of public cultural and educational organizations and cooperatives and to organize local self-government.

Under the pressure of the German military administration, on July 25, 1941, Andrey Sheptytsky addressed to the harvesting farmers: "The team of the German army asks me to instruct the Highly respected clergy to announce to the people the proclamation of the German Economic Commission... The believers must be encouraged to work harder and more properly on their farm lands because it depends on their own future livelihood, covering all expenses and rebuilding the economy". However, in the end he also mentioned "the help to the German army through the sale of farm products to the so-called collection points" 340 .

There were some attempts to consolidate the right-wing Ukrainian politics. In August 1941, the first organizational meeting of representatives of the OUN of Bandera and Melnik directions was held in the Metropolitan Chambers with the participation of Andrey Sheptytsky and Josyf Slipyj. But it failed ${ }^{341}$. The unity was not achieved. With the assistance of Metropolitan, in 1942 negotiations were held in Lviv among the OUN and the representatives of the Polish underground. Unfortunately, coordination of military-political efforts against the Nazis was not achieved again ${ }^{342}$.

During that period, the UGCC was doing everything possible to support people on spiritual level, to preserve their high moral and ethical values. The priests called to maintain a Christian family life. The Church strongly condemned Nazis' terror and repressions as methods of political struggle. Metropolitan A. Sheptytsky expressed his negative approach to terror and repressions in his famous pastoral

\footnotetext{
339 Малик Я., Сурмач О. Преса про діяльність Української греко-католицької церкви в період німецької окупації. Українська періодика: історія і сучасність. Львів, 1999. С. 169-173.

${ }^{340}$ Ibid

341 Архів СБУ у Львівській області. Спр. П-32693 (Сліпий Й.). С. 44-45.

342 Потічний П. У ПА та німецька адміністрація. Зустрічі. 1991. № 2. С. 137-142.
} 
letter "Do not kill" (November 21, 1942). He warned that the curse of the church would fall on all who sheds innocent blood ${ }^{343}$.

The confrontation between the UGCC led by Metropolitan A. Sheptytsky and the Nazi regime manifested itself with the increasing terror in the occupied territories. In a letter to Pope Pius XII on August 31, 1942, he angrily wrote about mass executions of Jews in Ukraine. He referred condemning the genocide of the Jews directly to A. Hitler. Only the patronage of Governor-General G. Frank saved Metropolitan from arrest. According to the witnesses, A. Hitler noted that A. Sheptytsky should be hanged for such actions, but Metropolitan A. Sheptytsky can afford it. It is also important that Metropolitan hided in his chambers and saved from the deaths Rabbi Ezekiel Levi and 150 Jews in the monasteries ${ }^{344}$. In 1942, Andrey Sheptytsky appealed to the Reich Commissar H. Himmler protesting against the use of extra police units in the raids against Jews.

Special attention was provided to the education of the young generations. In July 1941, six kindergartens were opened in Lviv and Andrey Sheptytsky personally greeted children in St. George's Cathedral. On the initiative of the church, kindergartens were also established in the cities of Zolochiv, Zbarazh and other settlements. Metropolitan ordination was fighting against the propaganda of atheism and called priests to catechize students, encouraged young people to study crafts and trades, organized a fundraising to help high school and professional youth. Archbishop Josyf Slipyj and Fr. Dr. Havryil Kostelnyk repeatedly served the Holy Mess and memorial services for students - victims of Bolshevik and Nazi terror. "Metropolitan Andrey Sheptytsky People's Hospital" with 82 employees, including 17 doctors and 18 nuns, was reopened ${ }^{345}$.

343 Кравчук А. Християнська соціальна етика під час німецької окупації Галичини, 1941-1944: Митрополит Андрей (Шептицький) про солідарність, опір владі та захист святості життя. Ковчег. Львів, 2000. Ч. 2. С. 224-269.

344 Гайова О. Митрополит Галицький. Украйнський альманах 2001. Варшава, 2001. С. 103; Кравченюк О. Велетень до Святоюрської гори. Торонто, 1963. C. 103 .

345 Малик Я., Сурмач О. Преса про діяльність Української греко-католицької церкви в період німецької окупації. Українська періодика: історія і сучасність. Львів, 1999. С. 172; Дітвора своєму опікунові. Рідна земля. 1943. Ч. 35; Краківські вісті. 1942. Ч. 146, 262; 1943. Ч. 4; Львівські архієпархіальні відомості. 1942. Ч. 5. С. 93; Ч. 6. С. 131. 
The care about scientists also continued. The scientific collection of "OSBM Notes" has been restored. The diplomas of Doctor of Theology were re-registered. Metropolitan repeatedly had meetings with leading scientists from the cities of Kyiv, Kharkiv, Dnipropetrovsk $^{346}$.

The Church helped to save lives of 40,000 Red Army prisoners of the German concentration camps in the Metropolitanate's territories. UGCC helped to 25,000 children evacuated from Pokuttya region during the terrible floods and provided other charity actions. Greek Catholic parishes sheltered the fugitive-priests from eastern Ukraine. Orphanages were established and taken under the protectorate in the towns of Zbarazh, Zolochiv and in the village of Voinyliv in Stanislav region $^{347}$.

On November 18, 1941, Alfred Rosenberg sent the Reichscomissar for Ukraine Erich Koch secret instructions, which recommended that churches and sects should be banned from political activities and public statements. The bishops were not supposed to be representatives of the Ukrainian nation, but officials appointed by the Ministry of the Occupied Territories of the East. His new instructions, dated by May 13, 1942, required that religious communities could exist only if they were not engaged in politics and were not dangerous for the German authorities ${ }^{348}$. There was a similar Nazi policy towards the religious communities of the Galicia District, which was part of the General Governorate (established on October 12, 1939).

The Ukrainian Central Committee (established in 1940 in Krakow, headed by professor-geographer Volodymyr Kubiyovych) and its regional representative - Ukrainian Regional Committee in Lviv (existed until 1942) tried to control the socio-cultural, in particular church-religious, life of almost 4.3 million Greek Catholics ${ }^{349}$. The

\footnotetext{
346 Малик Я., Сурмач О. Преса про діяльність Української греко-католицької церкви в період німецької окупації. Українська періодика: історія і сучасність. Львів, 1999. С. 172.

347 Антонюк Н.В. Українське культурне життя в «Генеральній губернії» (19391941). Львів: Наукова бібліотека ім. Стефаника, 1997. С. 166; Державний архів Львівської області. Ф. 3, оп. 1, спр. 71, арк. 118.

348 Лисенко О. Церковне життя в Україні. 1943-1946 pp. Київ: Інститут історії України НАНУ, 1998. С. 13.

349 Антонюк Н. В. Українське культурне життя в «Генеральній губернії» (19391944 рр.). Львів, 1997. С. 16-28; Жуковський А., Субтельний О. Нарис історії 
clergy played a significant ideological and organizational role in the social activities of these political structures. In particular, almost all 32 UCC delegates in the Galicia district were in different periods headed by Greek Catholic priests Fr. Y. Pleshkevych Fr. M. Yuzvyak, Fr. S. Leshchynsky, Fr. Dean M. Rusyn, Fr. I. Hodunko ${ }^{350}$.

During the spring of 1940, an advisory Council for the Affairs of the Greek Catholic Church was established. This council was aimed to resolve the social and territorial-organizational problems that arose in connection with the new conditions of religious life. Representatives of the council provided material help to priestsUniates from the East, placed them in Greek Catholic parishes, searched for them a job places in secular institutions and asked for financial assistance from the government ${ }^{351}$.

The church repeatedly warned citizens from unwise actions, called to be politically restrained and not to be involved into interethnic provocations by the Nazis and Polish chauvinists and rebel leaders ${ }^{352}$. The warning came from the general guidelines of the church, which at the period of the devastation of human souls and the devaluation of human life actively opposed the most terrible sin - human killing. This issue was discussed at the third and fourth archdiocesan councils of $1942-1943^{353}$. The fifth council of 1944 once again drew the attention of the people to the struggle against disagreements, hostility and hatred among the nations, which "in the storm of war, only grows" 354 .

України. Львів, 1992. С. 117; Кубійович В. Українці в Генеральній Губернії. 1939-1941. Історія Українського Центрального Комітету. Чикаго, 1975. С. 3-12; Шаблій О. Володимир Кубійович: Енциклопедія життя і творення. Париж; Львів, 1996. 704 с.; ЦДІАУЛ. Ф. 408. Оп. 1. Спр. 631. Арк. 2-8.

350 Лисенко О. Церковне життя в Україні. 1943-1946 pр. Київ: Інститут історії України НАНУ, 1998. С. 21.

351 Антонюк Н. В. Українське культурне життя в «Генеральній губернії» (19391944 рр.). Львів, 1997. С. 157.

352 Слово Митрополита. Краківські вісті. 1943. Ч. 179; Послання Всепреосв. Митрополита Кир. Андрея до Духовенства і вірних. Львівські архієпархіяльні відомості. 1943. Ч. 8/9. С. 109-110.

${ }^{353}$ Антонюк Н. В. Українське культурне життя в «Генеральній губернії» (19391944 рр.). Львів, 1997. С. 164-165; Львівські архієпархіяльні відомості. 1942. Ч. 12. С. 205- 208; 1943. №6/7. С. 85-88. Ч. 8-9. С. 109-110.

354 Львівські архієпархіяльні відомості. 1944. Ч. 1/3. С. 3. 
The UGCC used all possible ways to revive the religious life, as well as to legally lead the spiritual life of the people and promote their national and cultural development. In 1943, the Church Archaeographic Commission was established as a center for the objective research of the history of Ukrainian churches. This commission united well-known scientists Ivan Krypiakevych, Dmytro Doroshenko, Oleksandr Ohloblyn and others ${ }^{355}$. However, they were not able to develop large-scale work.

The hierarchy of the Greek Catholic Church tried to have a dialogue with the Ukrainian Autocephalous Orthodox Church and the Autonomous Orthodox Church, which operated in the western region during World War II. It should be noted that not only in Galicia, but also in the Dnieper Ukraine, the Germans quite calmly welcomed the revival of the Ukrainian Orthodox Church ${ }^{356}$. The occupation authorities returned the temples and monasteries to the believers, which were confiscated by the Stalin regime. The authorities also allowed the resumption of the UAOC, destroyed by the Bolsheviks, headed by Archbishop P. Sikorsky, and the development of the church structures of other denominations, educational institutions, and publishers that published religious literature. Archival documents show that the Soviet government was well-informed and had all detail information about the church policy of Berlin on the occupied territories, which caused discomposure for Stalin and forced him to take urgent measures.

In the fall of 1943, the Kremlin leaders radically changed their church policies. Some additional factors that are important in the context of war actions caused this situation. The war testified to the low morale and political spirit of the army, destroyed by violent collectivization, famine, mass repressions and terror by the Stalinist regime against its own people. As a consequence, the millions of soldiers and commanders of the Red Army were captured during the first months of the war. There were hard military defeats, and a million of Soviet people joined the ranks of the Wehrmacht and the police. In order to uplift the moral and political spirit of the army and the people, Stalin had to forget about some communist postulates like

355 Логос. 1995. Т. 4. Кн. 3. С. 135-147.

356 Центральний державний архів громадських об'єднань України (ЦДАГО України). Ф. 1. Оп. 23. Спр. 45. Арк. 16. 
"religion is the opium of the people" and to reconsider the attitude towards religion and the church. The allies - members of the antiHitler coalition: The United States, England, France also played important role. The allies-states did not accept Moscow's brutal attitude towards religion because of violation of the human rights declared by the Constitution and acts of the League of Nations.

On September 4, 1943, for the first time in 20 years, there was a meeting of the head of the Soviet state, J. Stalin, with the hierarchs of the Russian Orthodox Church, who, headed by Metropolitan Sergey, survived in the horrific repressions. Important decisions were adopted on the support of the church by the state: the call of the Council, the opening of temples and spiritual educational institutions, the increasing of rights and freedoms of religious communities, the release from prisons and concentration camps of the repressed church leaders. The Council for ROC Affairs was established under the Soviet People's Commissar. Stalin appointed NKVD Colonel G. Karpov as a chairman of the council ${ }^{357}$. Undoubtedly, the main purpose of the "religious revival" in the USSR, initiated by Stalin during the war, was to use the church and its authority among compatriots to implement pragmatic political and ideological plans in the country and beyond. The communist regime had never allowed the church to participate in the ideological sphere of society, in the education of the Soviet people.

The communist leaders of Moscow and Kyiv have already developed a specific attitude towards the Ukrainian Greek Catholic Church. It was associated with "Ukrainian bourgeois nationalism" because it remained a source of the Ukrainian national idea, an effective factor in the formation of the consciousness of Western Ukrainians. Moscow considered the UGCC as a collaborator, arguing that all 32 Galicia district delegates were headed by Uniate priests. The other argument was that the church participated in the formation of the Ukrainian division "Galicia" within the Wehrmacht,

357 «Русская православная церковь стала на правильный путь». Докладные записки председателя Совета по делам Русской православной церкви при СНК СССР Г.Г. Карпова И.В. Сталину 1943-1946 гг. Исторический Архив. 1994. Т. 3. C. $139-148$. 
maintained contacts with the German administration, and at the same time assisted the "Bandera followers"

There was a department of spiritual guardianship under the Military Administration of the "Galicia" Division. It was headed by the Vice-Rector of the Lviv Theological Seminary, Professor of the Lviv Theological Academy, Doctor of Theology Vasyl Laba, who signed the official documents as the "Referent of the Pastoral Office under the Main Directorate of the "Galicia" Division"359. On the request of Bishop Hryhori Khomyshyn, at the beginning of July, 1943, on the square in Stanislaviv the future soldiers of the division were blessed by Bishop Ivan Lyatyshevsky, a leader of the Ukrainian national bulletin "Nova Zoria", and by several priests. In April 1945, this fact became the basis for the arrest and numerous interrogations of a leader of the "nationalist organizations" and, consequently, his exile to the Jambul region of Kazakhstan ${ }^{360}$.

As for Bandera movement, throughout the Nazi occupation period, Greek Catholic priests not only actively worked in the fields of culture and education, took care of the spiritual status of the believers, but also aided the Ukrainian resistance movement represented by OUN and the UPA. Monasteries and churches were the spiritual and material support for the rebels and underground in their struggle against the Nazis, and later against the Stalinist regimes. Based on the principles of Christian morality, the Metropolitan Consistory forbade the clergy to engage in the armed struggle. However, it was closely connected with the people and did not stand apart from the tragedy of the land. The monasteries assisted the wounded UPA soldiers. In the Monastery in the village Uhniv, Peremyshliany district in the Lviv region, an underground hospital for the ill rebels was operating ${ }^{361}$.

The contacts between insurgents and Ukrainian authorities in the eastern Ukraine maintained. The Ukrainian National Council (established on October 5, 1941 in Kyiv with the participation of the OUN-M) tried to harmonize both church-religious and national life. To this aim, the Ukrainian Church Council was formed, which in

\footnotetext{
${ }^{358}$ Боляновський А. Дивізія «Галичина». Історія. Львів, 2001. С. 118-127.

${ }^{359}$ Ibid. C. 44-45.

${ }^{360}$ Соколовський О. Слуга Божий Спископ Кир Іван Лятишевський: хронологія останніх років земних скитань. Нова зоря. 1993. Вересень. Ч. 33-34.

361 ДАЛО. Ф. 3. Оп. 1. Спр. 436. Арк. 148.
} 
early 1942 decided to ask A. Sheptytsky to become a Patriarch of the UAOC. It is well known that the revived autocephalous eparchies were extremely poor - both financially (lacking church utensils, liturgical books) and organizationally (lacking staff, educational institutions). This request was formally presented to Metropolitan in April in Lviv by Fr. J. Kladochny ${ }^{362}$. However, the proposal was not accepted. At the same time, Metropolitan A. Sheptytsky did not refuse assistance to the autocephalists, noting that "those not-united, who will accept the Catholic faith, do not renounce the Orthodox faith, but supplement it with the doctrine of the Catholic Church, the united thought" ${ }^{363}$.

Already mentioned Joseph Kladochnyi maintained in Kyiv the relations with the head of the Ukrainian National Council M. Velychkivsky, the mayor of the city of Kyiv, prof. V. Bagaziy, deputy chairman of the Leadership of the Ukrainian Nationalists, archaeologist and poet O. Olzhych-Kandyba, Ukrainian leader of the Kuban region in 1917-1921, S. Manchula. Together with Fr. J. Kladochnyi, a catholic pastor Yuri Protsyuk was engaged in pastoral activity in the capital. In 1941-1942, Greek Catholic parishes were established for tens of thousands of Galicians living in the cities of Kamianets-Podilskyi, Proskuriv, Vinnytsia, Zhytomyr, and even Chernihiv $^{364}$.

Unfortunately, the leadership of the church failed to make agreement with the command of the Army Craiova, whose militants inflicted many grievances on individual parishes and patriotic laymen not only in Zakerzonia and Volyn, but also in Galicia ${ }^{365}$.

However, the church leadership tried to get in touch with the restored Soviet authorities in the fall of 1944. In October, seriously ill Andrey Sheptytsky sent a letter to the Council on Religious Affairs under the USSR government. However, Metropolitan died on November 1, 1944, in the middle of his actions to protect the church in a new situation. His majestic funeral in Lviv, to which Khrushchev arrived with a wreath from Stalin, turned into a demonstration of the

362 Шкраб'юк П. Виноградник Господній; Історія життя о. д-ра Йосифа Кладочного. С. 167-168.

363 Ibid.

${ }^{364}$ Ibid. C. 168-170.

${ }^{365}$ Каспришин Р. Іродів ніколи не бракувало. Місіонар. 2001. № 2. С. 57. 
power of the Greek Catholic Church in the western region. The Metropolitan throne was occupied by Josyf Slipyj, who in November congratulated the "liberators" and in December 1944 sent to Moscow a venerable delegation of Greek Catholic hierarchs, led by Archimandrite Klymentiy Sheptytsky. The delegation was received by the Council on Religions under the Government of the USSR. During the negotiations, the head of the commission conveyed the letter of Metropolitan to Stalin ${ }^{366}$. Another letter to the Government substantiated the request not to interfere with the activities of the UGCC. The delegation also donated 100 thousand rubles to the Red Cross Fund. After consulting with V. Molotov and M. Khrushchev, Chairman of the Council, Colonel I. Poliansky, on behalf of the Soviet leadership, stated that the Ukrainian Catholic Church has equal rights with other denominations operating in the USSR and may operate within the framework of existing legislation. It is clear that I. Polyansky informed Stalin in detail about the course of the five-day negotiations (December 22-27, 1944). Obviously, in connection with the war, the "leader of the nations" did not want to engage in open conflict with the UGCC ${ }^{367}$.

During the offensive of the Soviet army in Lviv, in July 1945, the OUN and the UPA distributed a leaflet "Ukrainian Greek Catholics" with the warning: "Let all the traitors and werewolves understand that while we, the Ukrainian rebels, are walking in the world, until then all the Stalin agents and ministers who help the Bolsheviks to lay the yoke on the neck of the peoples will be taught our insurgent custom, no matter who it is ${ }^{, 368}$. It is clear that the church hierarchy tried to avoid the mass bloodshed in the region, which was criticized by some rebel commanders.

In the 1940s-1950s, 200 priests of the Stanislav eparchy were repressed for the support of the "bourgeois nationalism". The spiritual bishops, who conveyed their pastoral messages to them even from a

\footnotetext{
366 Одинцов М.И. Путь длиною в семь десятилетий от конфронтации к сотрудничеству: государственно-церковные отношения в истории советского общества. На пути к свободе совести. Москва, 1991. С. 64; ЦДАГО України. Ф. 1. Оп. 23. Спр. 1638. Арк. 17-18.

367 Білас I. Репресивно-каральна система в Україні 1917-1953. Кн. 1. Київ: Либідь - Військо України, 1994. С. 310.

368 Сергійчук В. Нескорена церква: подвижництво греко-католиків України в боротьбі за віру і державу. Київ, 2001. С. 72-75.
} 
distant Siberian exile, did not leave their faithful in this difficult time, asking "to maintain their parental faith, their native fatherland, their churches and their homes, their language and God's truth"369.

So, after the liberation of the western region from the Nazi invaders, a new phase in the history of the church begins. The change in Stalin's course on religion during the war (1943) marked the transition of authorities from fierce confrontation to a more flexible policy on the church and the believers. The reasons for switching to partnership mode were not in the attempts to democratize the regime, but in the desire to camouflage its repressive nature, to suppress the image of a post-war "socialist" society in the eyes of the world public. However, in the early postwar years, many believers and some of the clergy were repressed. It is important that according to court sentences, they were not punished for pastoral activity, but as "enemies of the people". At the same time, the clergy and believers were constantly under the control of the state security agencies, who sought to turn the "separate" church into tools for strengthening of the totalitarian regime in the new regions of the UkrSSR.

Some sort of tolerance of the Soviet power to the church did not last long: in 1946 the regime organized a Lviv "council", which in fact drove the UGCC into the underground, which lasted until the end of the $1980 \mathrm{~s}^{370}$. The forced confessional-institutional transformation of the region's largest church was caused not so much by military and political circumstances as by the arguments of the strategic plan - by the need to neutralize the patriotical priesthood, which did not accept communist social ideals, politics of the Sovietization, and which spiritually supported the Ukrainian rebels.

\footnotetext{
${ }^{369}$ Ibid. C. 27.

370 Лисенко О.Є. Церковне життя в Україні. 1943-1946 pp. Київ, 1998. С. 245-363; Ковчег. Львів, 2002. Ч. 2. С. 165-188.
} 